\title{
Indirect Effect of CSR Disclosure on The Relationship of Gender Diversity on Company Performance
}

\author{
Sari Rahmadhani ${ }^{1}$, Dias Nurlita ${ }^{2}$, Dhian Anandarini Minar savitri ${ }^{3}$ \\ Accounting Program, Sekolah Tinggi Ilmu Ekonomi Totalwin, Semarang, Indonesia ${ }^{1,2,3}$ \\ \{ sari@stieltotalwin.ac.id ${ }^{1}$, diasnurlita15@gmail.com², dhian@stietotalwin.ac.id $\left.{ }^{3}\right\}$
}

\begin{abstract}
This study aimed to determine the effect of gender diversity and corporate social responsibility and to find out the influence of corporate social responsibility in mediating the relationship between gender diversity and company performance. This study uses secondary data from companies listed on the Indonesian Stock Exchange. Research sample selection employed was purposive sampling. The research data analysis were double regression analysis. It was found that gender diversity and CSR had a positive effect on company performance. CSR was proven to mediate relationship of gender diversity to company performance. Improved financial performance influenced by gender diversity will develop better through social and environmental concerns expressed in CSR disclosure. The results of this study can be a policy recommendation for Indonesian government to improve the development of sustainable development programs for companies.
\end{abstract}

Keywords: CSR, Gender diversity, Company performance

\section{Introduction}

Sustainable development programs through the achievement of Sustainable Development Goals (SDGs) have a great opportunity to be applied in Indonesian companies. Companies in the industrial sector, especially non-financial sector, achieve sustainable development goals by exploring synergies among stakeholders to improve company performance. Currently, good company performance is not only reflected in company's profitability, but also on company's good governance. The company governance structure should clarify the rights and obligations within the company. A good governance has interconnected rules and procedures within the company thus facilitating decision making at top management level. These elements of governance include board of directors, managers, shareholders and society. Board of directors is responsible for determining company's strategic goals and managing company's daily activities [1].

Board of directors and board of commissioners as top management are expected to be capable of making objective and comprehensive decisions. To achieve this goal, a genderdiverse top management can enrich information, perspective and objectivity in decision making. Along with implementation of SDGs in gender equality, gender diversity is still in a relatively low position. The results of a survey conducted by National University of Singapore Business School showed that proportion of women in top management in Indonesia is still 
relatively small, only $11.6 \%$. While for the proportion in board of directors is $1.31 \%$ and board commissioners is $9.9 \%$.

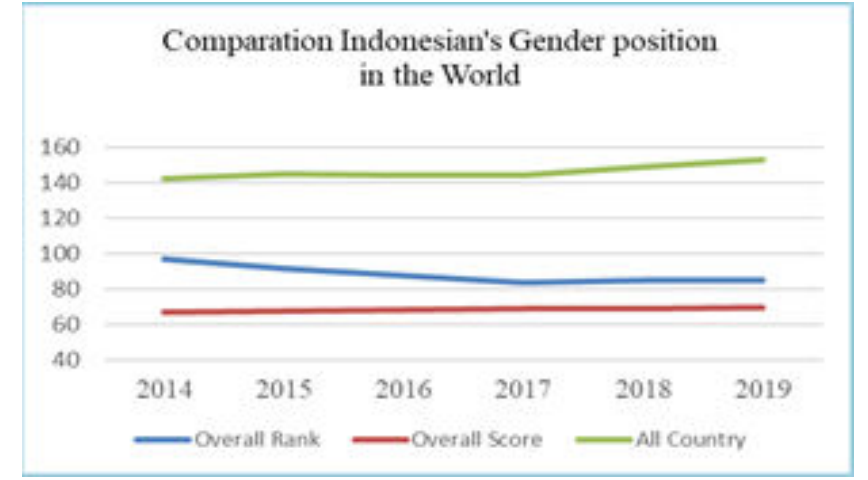

Fig 1. gender equity position

It can be seen from table 1.The 2014-2018 Global Gender Gap report launched by World Economic Forum (WEF) shows that position of gender equality in Indonesia for 6 consecutive years tends to be stable, even though ranking of total of all countries tends to decline. Gender diversity in top management is interesting to discuss because of governance in Indonesia. The presence of women in top management makes better financial performance and governance. Women tend to have a more resilient attitude and a higher level of commitment, so they can manage the company better. Women also tend to be more democratic in leading since they involve their subordinates in decision making. This encourages the creation of a more comfortable work environment, resulting in performance increase on each sector thus developing increase in performance of the whole company. In addition to gender diversity, the implementation of SDGs is CSR implementation. This is supported by a recent PwC report which found that $71 \%$ of business activities are currently developing social and environmental awareness activities in accordance to corporate sustainability practices [2]. Several studies examining the effect of CSR disclosure on company performance have shown positive results.

Disclosure of corporate social responsibility (CSR) can be used by users or viewers of company information to assess the company's concern in social activities so that it will attract the society to consume the company's products, which in turn increase profitability. The relationship between gender diversity in top management can influence information on CSR activities among stakeholders with CSR disclosure [3]. Gender diversity can carry out and disclose CSR activities more objectively in financial reports. This study aimed on testing whether gender diversity and CSR disclosure can improve company performance. This research also examined whether the influence of gender diversity in improving company performance has to be through CSR disclosure. This would answer whether gender diversity and CSR disclosure allows companies to increase the company's sustainability. This phenomenon is very basic because well-implemented CSR practice is a strategic factor in using resources and strengthen the company's position in improving sustainable CSR performance [4].

This research is expected to enrich knowledge in understanding companies' strategy in implementing sustainable development programs in Indonesia. implementation of the SDGs which includes the achievement of gender equality (the fifth goal) and CSR implementation (twelvth goal) as well as the achievement of economic improvement (the ninth goal). The results of this study also provide empirical evidence such as the first, regarding the effect of 
gender diversity on company performance. The second is about CSR disclosure on company performance and the third is that CSR disclosure mediates relationship between gender diversity and company performance. This research is expected to contribute to companies in interpreting the demands of stakeholders in decision making made by top management. These decisions consider gender equality and social and environmental responsibilities to achieve the company's sustainable goals.

Companies that want sustainable business will make CSR activities as mandatory activity and put include them in their annual report. The first research result is that women involvement showed gender diversity which actively reduced the company's performance in top management. Gender diversity that is actively involved in top management reduces company performance, this happened because gender diversity reduces courage in making important strategic decisions resulting in profit decrease. Gender diversity weakens the ability to take greater risks and thus reduces the company's performance.

The second result is that gender diversity in top management increased CSR disclosure. Gender diversity contributes to determining the objectives of CSR implementation. CSR can provide a positive social image for stakeholders. So that both consumers and investors will prefer companies that carry out social activities [5]. And the third result is a better relationship between gender diversity and company performance through CSR disclosure. This shows that gender diversity in carrying out CSR activities disclosed in the financial statements will improve sustainable company performance.

\section{Research Method}

\subsection{Resource Dependence Theory}

Resource Dependence Theory is a theory that focuses on external relations with the power held by the most important divisions to overcome and solve organizational problems arising from the surrounding environment [6]. The company's board of directors connects the company with external organizations. Gender diversity in top management and middle management positions can leverage various company resources for the better. Resource dependence theory suggests that gender diversity in top management and middle management positions has the potential to increase the information provided by the board of directors to managers. The composition of top management with gender diversity will produce unique information used for better decision making. Gender diversity in top management can provide access to important constituencies in the external environment. Diversity promotes greater creativity, innovation and quality decision making. Gender diversity in top management and middle management is expected to provide added value effecting in a better company performance.

\subsection{Company Performance}

Company performance is an indicator of success and achievement achieved by the management. Performance appraisal is carried out to determine the performance achieved. Measurement of financial performance based on applied accounting were taken through financial ratio. Financial ratio helps to identify the company's weaknesses and strengths. Financial managers use financial ratio to measure the company's performance overtime [7]. Company performance is measured by the effectiveness of the company in generating profits 
by utilizing its assets. Profitability ratios as measured by return on assets show the effectiveness of management in using assets to generate income [8].

\subsection{Gender Equality}

Gender diversity at top and middle management levels is interesting to study because in Indonesia there are opinions saying men are better off in leadership positions in companies. Men's success is considered because of high ability (in terms of talent or intelligence). This causes the proportion of women in important positions to remain small, because it is considered that men have higher abilities than women. On the one hand, women are very cautious, tend to avoid risks, and are more conscientious. Women do not rush into decisions. For this reason, the presence of women on the board of directors is said to be able to help make wiser decisions and have lower risks [9]. The presence of women in top management reinforces better financial performance and governance. This is possible because women tend to be more resilient and have a higher level of commitment, so they can manage company better. In addition, women also tend to be more democratic in leading where they involve their subordinates in decision making. This leads to a more comfortable work environment so that the performance of each sector increases and in end it improves company's performance [10] .

\subsection{Corporate Social Responsibility}

Corporate social responsibility (CSR) is an accountability effort carried out by companies to meet the needs of stakeholders, both for internal and external interests. Company embodies responsibility for social and environmental problems in the form of CSR activities. Companies are part of society and environment, their existence is inseparable from society and environment. Companies should not develop themselves without paying attention to society and the environment. CSR is a company's commitment in carrying out its operational activities to always make a positive contribution to the social and environmental community. Implementation of corporate CSR can be undertaken by reporting CSR which is disseminated to public through company's annual report. The more companies disclose their social responsibility and the better the disclosure is, the higher company's performance will be. Healthy financial performance conditions and the company's efforts to maintain the environment and good relations with community through CSR will increase company's value and obtain expected benefits [11].

\subsection{Hypothesis Development}

\section{a) Effect of Gender Diversity on Company Performance}

Resource Dependence Theory is a theory that focuses on external relations with the power held by the most important divisions to overcome and solve organizational problems arising from the surrounding environment. Resource Dependence Theory suggests that the diversity of boards of commissioners and directors has the potential to enhance information provided by boards to managers because of the unique information acquired by the diverse board compositions. The diversity of the board is expected to provide added value effecting in a better company performance [6]. Women are also considered have effective role than other members. This is possible because women tend to be more resilient and have a higher level of commitment, so they can manage the company better. Women also tend to be more 
democratic in leading where they involve their subordinates in decision making. This attitude can leads to a more comfortable work environment so that the performance of each sector increases and eventually improves the company's performance[7]. The percentage of female directors has a significant positive effect on company performance as measured by return on income and return on assets [12]. Gender diversity has a positive effect on company performance so that the more the women in top management, the more effective decisions and ultimately improves company performance [13] and [14]. Based on previous research and existing theories, the hypotheses proposed in this study are as follows:

H1: Gender diversity has a positive effect on company performance.

\section{b) The Effect of CSR on Company Performance}

Stakeholder theory is a collection of policies and practices related to stakeholders, values, legal provisions compliance, community and environmental respect, as well as the commitment of the business world to contribute to sustainable development. Companies not only operate for their own interests, but must provide benefits for their stakeholders (shareholders, creditors, consumers, suppliers, government, local communities, and society in general). To fulfill stakeholder desires, Companies can use CSR as their strategy. Stakeholders will give full support to the company's activities if their CSR are disclosed properly, so that the companies' goals to improve their performance can be achieved [15]. The company discloses its social reports to avoid costs incurred if not reporting or not carrying out social responsibility activities, to prevent the company's financial performance from decreasing [11]. CSR disclosure is related to continuous improvement of company performance. Company activities that consider social and environmental impacts in short and long term can have an impact on improving company performance. CSR disclosure as a means of communicating social and environmental performance in a holistic manner helps companies to obtain license to operate from the government and the public [16] . CSR performance has a positive and significant impact on company performance [13] . Based on previous research and existing theories, the hypotheses tested in this study are as follows:

$\mathrm{H}_{2}$ : CSR has a positive effect on company performance

\section{c) The Influence of Gender Diversity on CSR}

Companies concerned their environmental responsibility to be accepted by community through CSR disclosures in companies' annual report. As there is a social contract between company and the community, CSR disclosure can be used as a medium of communication which to improve legitimacy between the two, increase future profits, and ensure sustainability of company's business [17]. Based on this theory, companies that have a certain percentage of women on their top management can perform CSR disclosure properly. The presence of women in top management is closely related to good corporate responsibility and compliance to social norms and values. The presence of women in board of directors contributes in assessing and disclosing CSR on high-profile companies on Indonesian Stock Exchange [18]. gender diversity has a positive effect on CSR [5], [19]. Woman as a main director gives a different color upon carrying out company's operations, they pay more attention to the issue of social responsibility. This has a positive impact on the company because the company will allocate more of its resources to good CSR implementation. Based on previous research and existing theories, the hypotheses tested in this study are as follows: $\mathrm{H}_{3}$ : Gender diversity has a positive effect on CSR 


\section{d) The Influence of Gender Diversity on Company Performance through CSR}

Many studies have supported a positive relationship between gender diversity and company performance [12]. If gender diversity has a positive effect on CSR practices of a company and CSR has a positive effect on company performance, it is expected that gender diversity on company performance will have a positive effect through CSR. It is considered that companies committed to CSR are also identified and assessed the demands of various stakeholders. The result is an increase in efficient corporate governance, which leads to adaptation to organizational change. The combination of gender diversity and CSR can influence the principals in decision makings. CSR fully mediates gender diversity in company performance [13]. If gender diversity at the top management board level affects company's CSR practices, then CSR has a positive relationship with company performance. It is predicted that companies are committed in carrying out CSR and assessed the demands of various stakeholders. The result is increase in efficient corporate governance, which leads to adaptation to organizational change, that is, successful changes in management processes. So that when gender diversity at the top management board level and CSR are combined, it increase the consideration of stakeholder needs. Based on previous research and existing theories, the hypotheses tested in this study are as follows:

$\mathrm{H}_{4}$ : Gender diversity affects corporate performance mediated by CSR.

\section{Methodology and Data}

Framework used as a tool for theoretical presentation, a description of the relationship between gender diversity and CSR on company performance will be explained. In this research, gender diversity was the independent variable, CSR was the intervening variable, and company performance was the dependent variable.

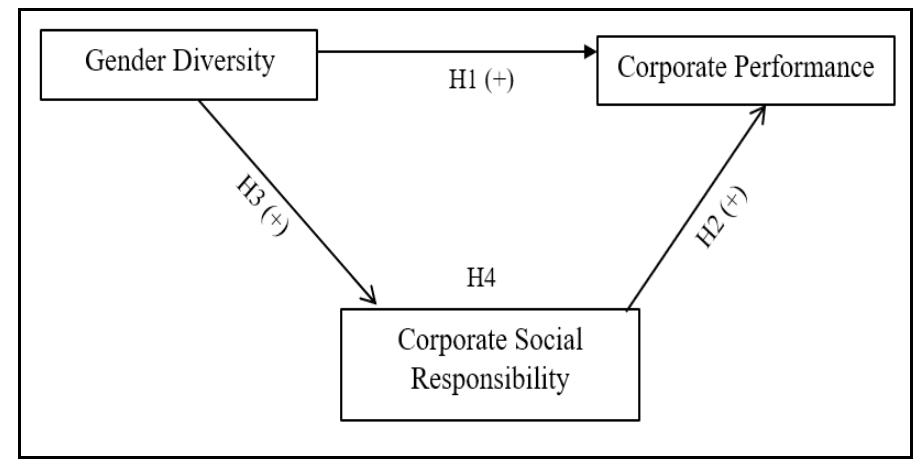

Fig 2. Framework

\subsection{Population and sample}

The research participant consisted of non-financial companies listed on the Indonesian Stock Exchange during the 2016-2018 period. These non-financial companies consisted of eight sectors: agriculture sector, mining sector, industrial and chemical sector, miscellaneous industry sector, goods and consumption industry sector, property sector, and trade sector. 


\subsection{Operational and Variable Measurement Definition}

This study examined the relationship between gender diversity and CSR disclosure. Company performance measured using Return on Assets (RoA). This ratio is calculated by net income divided by total assets. Gender diversity determined by the gender composition in top management. In this study, the gender diversity was the position of director, commissioner, audit committee, company secretary, remuneration committee and head of internal audit. Gender composition was measured by the Blau Index [20]. The Blau Index obtained by adding the squared results of the male and female fraction values. Thus, once the fraction of one gender reaches the level of 50 percent, the condition becomes more diverse (heterogeneous), otherwise the conditions would be less diverse (homogeneous). The Blau Index is formulated as follows

$\mathrm{Bi}=1-\Sigma \mathrm{pi} 2$

$\mathrm{Bi}=$ Blau Index

pi $=$ Number of Women on each group

CSR Reporting Index (CSRRI) measured by marking to be disclosed by the company in accorandce with the CSR GRI G4 terms. The CSR reporting formula developed in this study was:

$\mathrm{CSRRI}=\Sigma_{n}^{1} \frac{x}{n} \times 100 \%$

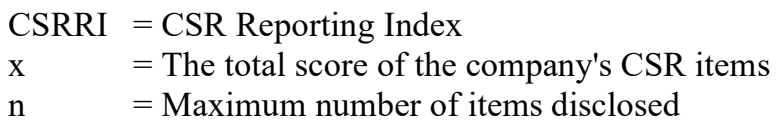

The control variable in this study was, the frequency of board of directors meetings as measured by the number of board meetings per year, company size, company size as measured by the natural logarithm ( $\mathrm{Ln}$ ) of sales, leverage was measured by total liabilities divided by total assets, board size was measured using the number of directors on the board of directors and the age of the company was measured starting from the date of establishment until the year this research was conducted

\section{Results and Discussion}

\subsection{Results}

This study used a sample of non-financial companies listed on the Indonesia Stock Exchange from 2016 to 2018. The data used were annual financial reports from 2016 to 2018 consisting of 980 data that met the research criteria. The results of variable descriptive test can be seen in the following table:

Tabel 1. Descriptive Statistics

\begin{tabular}{lccccc}
\hline & $\mathbf{N}$ & Minimum & Maximum & Mean & Std. Deviation \\
\hline ROA & 980 & -.58 & .16 & .0333 & .04853 \\
\hline
\end{tabular}




\begin{tabular}{llllll}
\hline Gender & 980 & .00 & .50 & .2223 & .14442 \\
CSR & 980 & .26 & .86 & .4373 & .12348 \\
Valid N (listwise) & 980 & & & & \\
\hline
\end{tabular}

The normality test using Kolmogorov Smirnov showed a significant value of the unstandardized residual of 0.057 , more than 0.05 . It can be concluded that the residuals are normally distributed. The multicollinearity test showed that the VIF value of all variables was less than $10 ;(1,020$ and 1,095) and the tolerance value for all variables was more than 0.1 $(0,980$ and 0,913$)$, so it was concluded that all independent variables were multicollinear.

Based on the results of glacier testing, heteroscedasticity was absent, it can be seen that the significant value of each independent variable (Gender, CSR, BOD Meeting, Size, leverage, BOD Size and Company Age) was greater than the 5\% probability of the residual (absolute) absolute value. So it can be concluded that the regression heteroscedasticity does not occur. The DW value was 1.206 , it can be concluded that the regression model was free from autocorrelation problems. The goodness of fit test as a test of suitability was equal with the results of certain observations and the frequency obtained based on the expected value or theoretical frequency can be seen in Table 2.

Table 2. Goodness of Fit Model Test Results

\begin{tabular}{llccccc}
\multicolumn{8}{c}{ ANOVA $^{\mathbf{a}}$} \\
\hline & Model & Sum of Squares & df & Mean Square & F & Sig. \\
\hline 1 & Regression & .784 & 7 & .112 & 71.574 & $.000^{\mathrm{b}}$ \\
& Residual & 1.522 & 972 & .002 & & \\
Total & 2.306 & 979 & & & \\
\hline
\end{tabular}

a. Dependent Variable: ROA

b. Predictors: (Constant), Company Age, Gender, Leverage, CSR, BOD Meeting, BOD Size, Size

Table 3. Hypothesis Testing Results Gender Testing on Company Performance

\begin{tabular}{|c|c|c|c|c|c|c|}
\hline \multicolumn{7}{|c|}{ Coefficients $^{\mathrm{a}}$} \\
\hline & \multirow[t]{2}{*}{ Model } & \multicolumn{2}{|c|}{$\begin{array}{c}\text { Unstandardized } \\
\text { Coefficients } \\
\end{array}$} & \multirow{2}{*}{$\begin{array}{c}\begin{array}{c}\text { Standardized } \\
\text { Coefficients }\end{array} \\
\text { Beta } \\
\end{array}$} & \multirow[t]{2}{*}{$\mathbf{T}$} & \multirow[t]{2}{*}{ Sig. } \\
\hline & & B & Std. Error & & & \\
\hline \multirow[t]{7}{*}{1} & (Constant) & -.166 & .020 & & -8.418 & .000 \\
\hline & Gender & .028 & .009 & .083 & 3.183 & .002 \\
\hline & BOD Meeting & .008 & .005 & .043 & 1.607 & .108 \\
\hline & Size & .007 & .001 & .276 & 9.402 & .000 \\
\hline & Leverage & -.030 & .002 & -.471 & -17.889 & .000 \\
\hline & BOD Size & .002 & .001 & .092 & 3.127 & .002 \\
\hline & Company Age & .000 & .000 & -.030 & -1.100 & .272 \\
\hline
\end{tabular}

a. Dependent Variable: ROA

Table 4. Hypothesis Testing Results of Gender Testing on CSR

\begin{tabular}{|c|c|c|c|c|c|c|}
\hline \multicolumn{7}{|c|}{ Coefficients $^{\mathrm{a}}$} \\
\hline & \multirow[t]{2}{*}{ Model } & \multicolumn{2}{|c|}{$\begin{array}{c}\text { Unstandardized } \\
\text { Coefficients } \\
\end{array}$} & \multirow{2}{*}{$\begin{array}{c}\begin{array}{c}\text { Standardized } \\
\text { Coefficients }\end{array} \\
\text { Beta } \\
\end{array}$} & \multirow[t]{2}{*}{$\mathbf{T}$} & \multirow[t]{2}{*}{ Sig. } \\
\hline & & B & Std. Error & & & \\
\hline \multirow{4}{*}{1} & (Constant) & .082 & .059 & & 1.401 & .162 \\
\hline & Gender & .109 & .026 & .127 & 4.147 & .000 \\
\hline & BOD Meeting & .068 & .015 & .140 & 4.486 & .000 \\
\hline & Size & .010 & .002 & .154 & 4.478 & .000 \\
\hline
\end{tabular}




\begin{tabular}{lccccc}
\multicolumn{7}{c}{ Coefficients $^{\mathbf{a}}$} \\
\hline Model & \multicolumn{2}{c}{$\begin{array}{c}\text { Unstandardized } \\
\text { Coefficients }\end{array}$} & $\begin{array}{c}\text { Standardized } \\
\text { Coefficients }\end{array}$ & T & Sig. \\
\cline { 2 - 6 } Leverage & -.004 & .005 & -.025 & -.806 & .420 \\
BOD Size & .007 & .002 & .110 & 3.209 & .001 \\
Company Age & .000 & .000 & -.029 & -.921 & .358 \\
\hline
\end{tabular}

a. Dependent Variable: CSR

The table 3 above showed that gender affects financial performance as seen on the significance value which was below 0.05 and the table 4 showed that gender affects CSR as seen on the significance value which was below 0.05 .

\subsection{Intervening Effect Detection Test}

The test of CSR role as an intervening variable to bridge the research gap between gender variables on company performance (return on assets) was taken by using sobel test calculation.

Table 5. Coefficients and standard errors

\begin{tabular}{lcr}
\hline \multicolumn{1}{c}{ Model } & B & Std. Error \\
\hline Gender - CSR & 0,109 & 0,026 \\
CSR - ROA & 0,032 & 0,011 \\
\hline
\end{tabular}

$$
\begin{aligned}
& t=\frac{a b}{\sqrt{b^{2} S E \alpha^{2}+a^{2} S E b^{2}}} \\
& t=\frac{0,109 \times 0,032}{\sqrt{0,932^{2} 0,020^{2}+0,109^{2} 0,011^{2}}} \\
& t=\frac{0,003438}{0,001459392} \\
& t=2,59003640
\end{aligned}
$$

From results of sobel test above and value of coefficient and standard error in table 5, it showed that the $t$ value was 2.39003640 , because $t$ value obtained is $2.39003640>1.96$ with a significance level of 5\%, it was proved that CSR was capable to mediate relationship between gender diversity and company performance. Gender diversity will better influence company performance through CSR. To find out whether there is perfect or partial mediation, it needs to be determined whether the coefficient $c$ " is statistically significant. If path coefficient $c$ " from the second step estimation result remains significant and unchanged $\left(c^{\prime \prime}=c\right)$ then there was no mediating effect. If the path coefficient $c$ " decreases $(\mathrm{c} "<\mathrm{c})$ but remains significant, then the mediation was partial mediation. If path coefficient $c$ " decreases $(c "<c)$ and becomes insignificant, the the mediation was full mediation. 


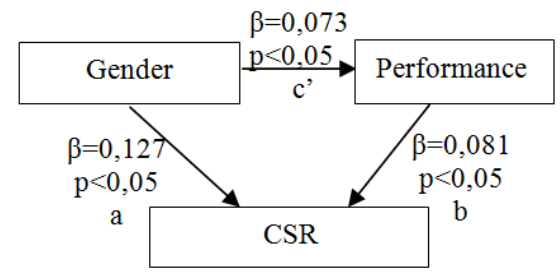

Fig 3. Relationship between Gender and Performance

In this stage coefficient $c^{\prime}$ value was 0.073 which was significantly smaller than $c$ coefficient value of 0.083 so it can be concluded that there was a partial mediation effect.

\subsection{Discussion}

Non-financial companies need to disclose CSR through annual reports because nonfinancial companies are very close to various environmental and social issues. It is expected that CSR disclosure can be a mean of company's communication to stakeholders so that it can improve its performance [13]. This supports the stakeholder theory which states that a good relationship with stakeholders can improve company performance through CSR disclosure. a company should not only operates for its own interests, but must provide benefits for its stakeholders (shareholders, creditors, consumers, suppliers, government, local communities, and society in general). To fulfill stakeholder desires, CSR can be used as a strategy. Stakeholders will give full support to the company's activities if CSR disclosed properly, so that the company's goals to improve company performance can be achieved [16].

Gender diversity in top and middle management can enrich information, perspectives and objectivity in decision making to improve company performance. Women tend to be more resilient and have a higher level of commitment, so they can manage the company better. In addition, women also tend to be more democratic in leading, where they involve their subordinates in decision making so that the performance of each area increases and eventually improve company performance [7]. The more the women in top management, the more effective the decisions will be made and ultimately improves company performance [13] [14]. Companies that have a certain percentage of women in top management and middle management can properly disclose their CSR. Women are cautious and careful in environmental and social issues so that they are expected to be excellent in supporting CSR disclosure in non-financial companies.

Women on board of directors can influence a company's CSR practices [13] The presence of women in top and middle management is closely related to good corporate responsibility and complying with social norms and values. The presence of woman on board of directors contributed in assessing and disclosing CSR to companies on the Indonesia Stock Exchange [18] [19]. The sobel test on effect of mediation (intervening) explained that CSR is significant as a mediator to bridge the research gap between gender diversity on company performance. This was caused by the greater the number of women in top and middle management who were involved in social activities, the more the assessment available for the company, because the company not only prioritizes things that are profitabile but also social. Indirectly, the presence of women in top and middle management can improve company performance through corporate social responsibility activities [13]. Gender diversity at the top management board level can affect the company's CSR practices, this means that CSR has a positive relationship with company performance. 


\section{Conclusion}

This study aimed to examine the ability of companies in Indonesia to implement sustainable development programs (SDGs). This study used the SDGs objectives, namely gender equality in gender diversity and social and environmental concerns in CSR. The tests conducted on non-financial companies resulted in appropriate results with the SDGs objectives: the influence of these two elements improved company performance. The study examined the gender diversity of those in top and middle management positions. The results showed that gender diversity in top and middle management positions in non-financial companies improved company performance. The result of gender diversity test increased CSR disclosure. This showed that gender diversity in top and middle management is essential in carrying out social activities, resulting in better CSR disclosures. The results of CSR disclosure test improved company performance and the test on CSR as a mediator of the relationship between gender diversity and company performance showed interesting results for non-financial companies. Gender diversity that initially improves company performance will eventually be better wit the help of CSR disclosure. This happens because gender diversity will make more CSR activities so that it can improve company performance. Future research is expected to add the duration of the research and take into account the value of future company performance to provide evidence of sustainability in the future.

\section{Reference}

[1] W. J. Carrington, K. Mccue, and B. Pierce, "Using Establishment Size to Measure the Impact of Title VII and Affirmative Action," vol. 35, no. 3, pp. 503-523, 2000.

[2] M. Nadeem, R. Zaman, and I. Saleem, "Boardroom Gender Diversity and Corporate Sustainability Practices : Evidence from Australian Securities Exchange Listed Firms Boardroom gender diversity and corporate sustainability practices : Evidence from Australian Securities Exchange listed firms,” J. Clean. Prod., vol. 149, no. April 2020, pp. 874-885, 2017, doi: 10.1016/j.jclepro.2017.02.141.

[3] B. F. Feijoo, S. Romero, and S. R. Blanco, "Does Board Gender Composition affect Corporate Social Responsibility Reporting ?," no. January, 2012.

[4] K. Rao and C. A. Tilt, "Board Composition and Corporate Social Responsibility : The Role of Diversity, Gender , Strategy and Decision Making," no. March, 2015, doi: 10.1007/s10551-015-2613-5.

[5] N. M. Rahindayati, I. W. Ramantha, and N. K. Rasmini, "Pengaruh Diversitas Pengurus Pada Luas Pengungkapan Corporate Social Responsibility Perusahaan Sektor Keuangan,” E-Jurnal Ekon. dan Bisnis, vol. 4, no. 5, pp. 312-330, 2015, doi: 10.1108/SAMPJ-10-2013-0042.

[6] J. Pfeffer and R. G. Salancik, The External Control of Organizations: A Resource Dependence Perspective. New York: Harper \& Row, 1978.

[7] N. N. Amin and Sunarjanto, "Pengaruh Diversitas Dewan Komisaris dan Dewan Direksi Terhadap Kinerja Perusahaan," Fokus Manajerial J. Manaj. dan Kewirausahaan, 2016.

[8] S. Muchtar and E. Darari, "Pengaruh Corporate Governance Terhadap Kinerja Perusahaan Manufaktur Yang Terdaftar di Bursa Efek Indonesia," vol. 5 dan 6, pp. 109-132, 2013. 
[9] S. Kusumastuti and P. Sastra, "Pengaruh Board Diversity Terhadap Nilai Perusahaan Dalam Perspektif Corporate Governance,” J. Akunt. dan Keuang., vol. 9, no. 2, pp. 88-98, 2014, doi: 10.1007/s00343-013-2058-6.

[10] McKinsey and Company, Women Matter Gender Diversity, A Corporate Performance Driver. 2007.

[11] J. J. Jekwam and S. Hermuningsih, "Peran Ukuran Perusahaan ( Size ) Dalam Memoderasi Corporate Social Responsibility Dan Likuiditas Terhadap Kinerja Keuangan Pada Perusahaan Pertambangan yang terdaftar di BEI," Upajiwa Dewantara, vol. 2, no. 1, pp. 76-92, 2017.

[12] Y. Liu, Z. Wei, and F. Xie, "Do women directors improve firm performance in China?,” J. Corp. Financ., vol. 28, pp. 169-184, 2014, doi: 10.1016/j.jcorpfin.2013. 11.016.

[13] M. S. Sial et al., "Does corporate social responsibility mediate the relation between boardroom gender diversity and firm performance of Chinese listed companies?," Sustain., vol. 10, no. 10, 2018, doi: 10.3390/su10103591.

[14] N. A. Jannah, "Pengaruh Gender dan Latar Belakang Pendidikan CEO terhadap Kinerja Keuangan Perusahaan Go Publik yang terdaftar di Bursa Efek Indonesia," 2018.

[15] I. Solihin, Corporate Social Responsibility From Charity To Sustainability. Jakarta: Salemba Empat, 2008.

[16] Y. M. Supadi and I. P. Sudana, "Pengaruh Kinerja Lingkungan dan Corporate Social Responsibility Disclosure Pada Kinerja Keuangan Perusahaan Sektor Pertambangan," E-Jurnal Ekon. dan Bisnis Univ. Udayana, vol. 4, 2018.

[17] A. S. L. Lindawati and M. E. Puspita, "Corporate Social Responsibility: Implikasi Stakeholder dan Legitimacy GAP dalam Peningkatan Kinerja Perusahaan,” 2015, doi:10.18202/jamal.2015. 04.6013.

[18] R. Hadya and R. Susanto, "Model Hubungan Antara Keberagaman Gender, Pendidikan Dan Nationality Dewan Komisaris Terhadap Pengungkapan Corporate Social Responsibility," J. Benefita, vol. 3, no. 2, 2018, doi: 10.22216/benefita.v3i2.3432.

[19] D. Setiawan, R. Tri Hapsari, and A. Wibawa, "Dampak Karakteristik Dewan Direksi Terhadap Pengungkapan CSR,” Ekuitas J. Ekon. dan Keuang., vol. VIII, no. 1, pp. 115, 2018.

[20] P. M. Blau, Inequality and Heterogeneity: A Primitive Theory of Social Structure. New York, NY, USA: Free Press, 1977. 